\title{
An Assessment of Cilacap Coast's Total Carbonate Sediment Content
}

\author{
Mukti Trenggono1,3*, Roy Andreas 2,3, Amron1, Rizqi Rizaldi Hidayat1,3, Hendrayana1,3, \\ Rr. Diah Febri Astuti ${ }^{4}$, Cristiana Manullang ${ }^{5}$
}

\author{
'Marine Science Department, Fisheries and Marine Science Faculty, Jenderal Soedirman University \\ ${ }^{2}$ Chemistry Department, Mathematical and Natural Science Faculty, Jenderal Soedirman University \\ ${ }^{3}$ Centre for Maritime Bioscience, Institute for Research and Community Services, \\ Jenderal Soedirman University \\ JI. Dr. Soeparno Kampus Unsoed Karangwangkal Purwokerto, 53122, Indonesia \\ 4 Institute for Marine Research and Observation, Ministry of Marine Affairs and Fisheries \\ Jl. Baru Perancak, Jembrana, Bali, 82251, Indonesia \\ ${ }^{5}$ Graduate School of Engineering and Science, University of the Ryukyus \\ Nishihara, Okinawa, Japan \\ Email: mukti.trenggono@unsoed.ac.id
}

\begin{abstract}
Sediments are particles derived from the dismantling of rocks from the land and pieces of shell and remains of marine organisms that contain organic matter, included carbonate sediment. The total carbonate sediment content was influenced by many factors, such as sediment grain type. This study aimed to determine the carbonate content in sediments and to determine their relationship to the sediment grain characteristic on the Cilacap coast. The sediment's carbonate content used the titration method, while the sediment grain test used a dry filter. Statistical analysis was used to determine the sediment grain characteristic (mean, sorting, skewness, and kurtosis). The results showed that sediments' total carbonate content had a range of $1.93 \%-6.23 \%$, with an average of $4.21 \%$. Sediments are dominated by fine sand with very well sorted, very platykurtic, and very fine skewed characteristics. The relationship between sediment grain characteristics and total sediment carbonate content showed a good correlation due to the sorting factor. Other parameters such as mean size and skewness have been shown a low correlation, whereas kurtosis has a shallow relationship with carbonate content.
\end{abstract}

Keywords: Carbonate; Cilacap coast; Sediment; Sorting

\section{INTRODUCTION}

The sand beach of tropical island composed of many bioclastic fractions derived from the calcium carbonate skeletons of coral reef creatures (Ford \& Kench, 2012; Smith \& Cheung, 2002), generally precipitated in organic form by biota in aquatic environments, and can also be directly precipitated from solution either in the open ocean (Trower et al., 2019) or as types of cement (Vousdoukas et al., 2007) and calcium carbonate (Moore \& Wade, 2013). Carbonates deposited in situ at the sedimentwater interface and in sediments have played a significant role in the carbon cycle throughout Earth's history (Saitoh et al., 2015; Higgins et al., 2009; Ridgwell \& Zeebe, 2005).
The carbonate in the solution settles between the sand and gravel material deposited on the beach, while the carbonate sediments' textures are usually well sorted (Nichols, 2009). Calcium carbonate is very susceptible to a solution that is emphasized by typically high coastal porosity and permeability (Pilkey et al., 2006). Porosity and permeability in minerals become a gathering place for deposits (Bohnsack et al., 2020).

Permeability is a measure of the ease with which water moves through the aquifer material (Dasgupta \& Mukherjee, 2020; Todd \& Mays, 2012). It is an essential property of natural unconsolidated sediment required to evaluate potential subsurface contaminant plume migration (National Research Council, 
2005). Various statistical parameters such as mean, skewness, and kurtosis play a role in determining sand's permeability (Ahr, 2008; Morrow et al., 1969). A specific relationship between the permeability and the statistical parameters describes the porous medium's grain size distribution (Masch \& Denny, 1966). Porosity is defined as the ratio between the pore volume and the total material (Mukherjee \& Kumar 2018; Flóvenz et al., 2012). In comparison, permeability is a function of porosity, grain size, and sorting. When combined, the sediment pores act as water channels to drain water through them (Gupta \& Ramanathan, 2019).

The difference in the pore capacity and the sediment's permeability in flowing solutions containing carbonates may occur in different sediment grains. This research was conducted to assess the carbonate content of various sediment grains and characteristics that play a role in determining the porosity and permeability of sediments. The research location is on the Cilacap coast, from $109.390^{\circ} \mathrm{W}$ and $7.725^{\circ} \mathrm{S}$ to $109.020^{\circ} \mathrm{W}$ and $7.745^{\circ} \mathrm{S}$ (Figure 1). The study location is divided into nine cells along the coast. Each cell consists of three stations with a distance of approximately $1.6 \mathrm{~km}$. The total number of stations is 27 , where it is assumed that each station has different utilization characteristics and coastal environmental conditions. The river that flows to the coast of Cilacap and its wave energy may carry sediment material and carbonate content. The combination of carbonate-producing organisms secretion activity from the sea and river flow can affect the carbonate content fluctuations in sediments on the Cilacap Coast.

\section{MATERIALS AND METHODS}

The method for determining sediment points used purposive sampling (Arikunto, 2010). Samples of sediment were obtained from 27 stations using a sediment core sampler in transition monsoon I. Figure 1 shows the locations of these stations. The first station (1.1) located in the east, which is bordered by karst

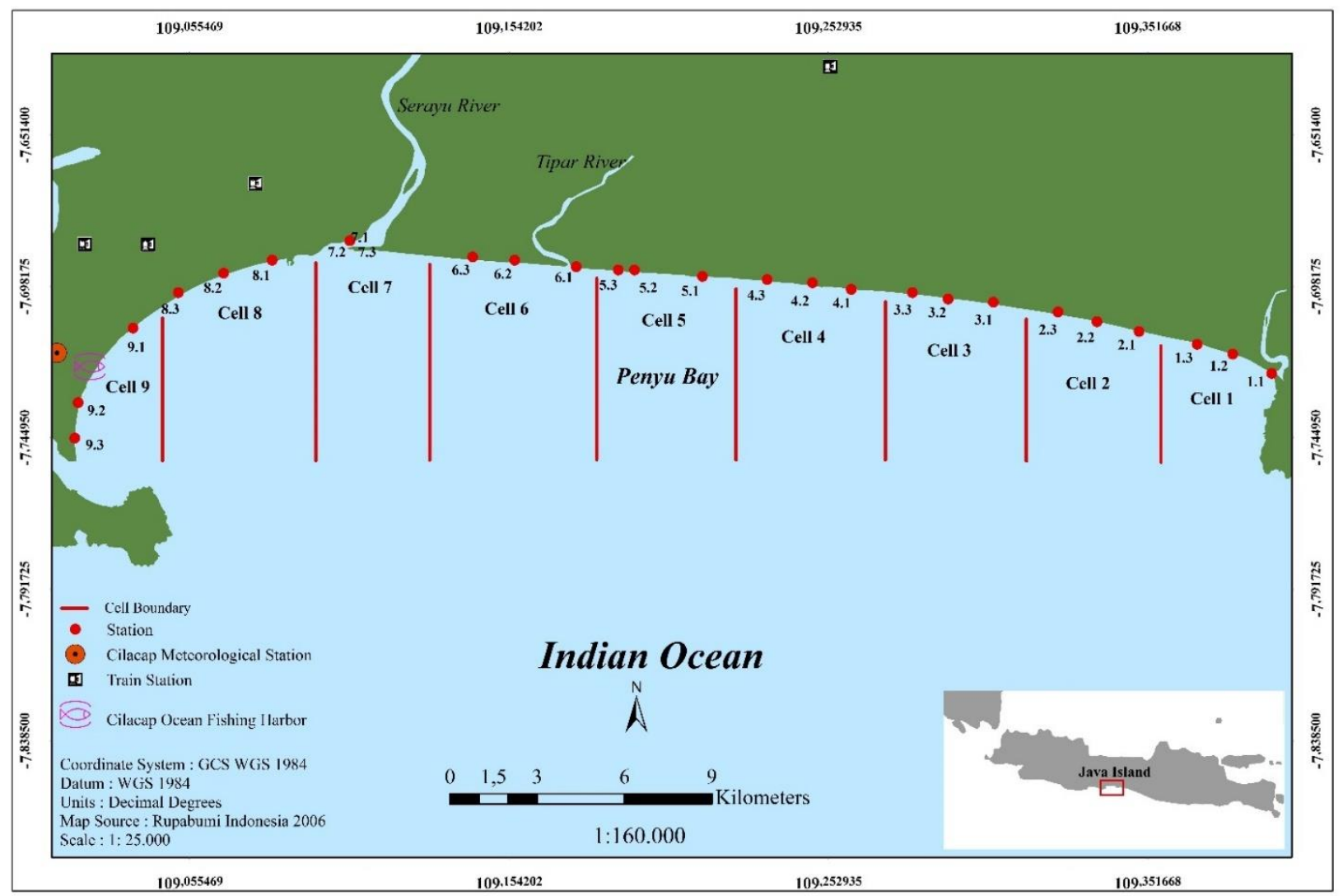

Figure 1. Study site area 
hills, and the last station (9.3) in the west, bordering the Nusakambangan island. The east and west stations are seasonally high wave energy. The east stations are affected by high wave energy in the northwest monsoon, while in the southeast monsoon, high wave energy reached the west station (Kutriyani \& Trenggono, 2018).

Samples of sediment from 27 stations were prepared prior to the analyses. Each sample was dried in an oven with a temperature of $100^{\circ} \mathrm{C}$. An analysis of grain sediments used dry samples and sifted using an Automatic Sieve Shaker in mesh size 0.075 $\mathrm{mm}, 0.106 \mathrm{~mm}, 0.150 \mathrm{~mm}, 0.250 \mathrm{~mm}, 0.425$ $\mathrm{mm}, 0.850 \mathrm{~mm}, 2 \mathrm{~mm}$. Each sample of 100 grams was shaken for 5 minutes, and then the sample weighed according to the retain weight on each mesh size. The calculation of the diameter fraction $(\varnothing)$ in phi $(\phi)$ units at the cumulative percentage of $5 \%, 16 \%, 25 \%, 50 \%$, $75 \%, 84 \%$, and $95 \%$ were carried out to calculate the sediment statistical parameters. The mean, sorting, kurtosis, and skewness calculated using the ASTM D 1 140-00 standard from the American Society for Testing and Materials (ASTM Committee D18, 2000). The formulas of each of these calculations are as follows (Folk \& Ward, 1957),

Mean size $(\mathrm{Mz})=\frac{\emptyset_{16}+\emptyset_{50}+\emptyset_{84}}{3} \ldots . .$. (Eq. 1)

The average grain size is an index of grain size measurements based on the percentage of each sample's fraction weight. The results obtained were the granules' size representing the sample (Friedman, 1978),

Sorting $(\delta 1)=\frac{\emptyset_{84}-\emptyset_{16}}{4}+\frac{\emptyset_{95}-\emptyset_{5}}{6,6}$. (Eq. 2)

Sorting is a statistical explanation for sorting grains. It is a measure of the range of grain size distribution in the sample,

Skewness $\left(\mathrm{Sk}_{\mathrm{i}}\right)=\frac{\emptyset_{16}+\emptyset_{84}-2 \emptyset_{50}}{2\left(\emptyset_{84}-\emptyset_{16}\right)}+$

$\frac{\emptyset_{5}+\emptyset_{95}-2 \emptyset_{50}}{2\left(\emptyset_{5}-\emptyset_{95}\right)}$

Skewness is defined as the degree of asymmetry of the standard or log-normal grain size distribution. The skewness can be positive or negative depending on the tail excess of fine or coarse particles, respectively,

Kurtosis $\left(K_{G}\right)=\frac{\emptyset_{95}-\emptyset_{5}}{2,44\left(\emptyset_{75}-\emptyset_{25}\right)}$

Kurtosis is the sharpness or peakedness of the grain size distribution curve.

The carbonate content was determined by the rapid titration method (Kennedy, \& Woods, 2013; van Reeuwijk, 1993) (Figure 2). Analysis of total sediment carbonate content was carried out by weighing 5 grams of sediment samples and using a standard example of 0.5 grams of $\mathrm{CaCO}_{3}$ powder. The sediment samples were put in a Duran bottle with added $100 \mathrm{ml}$ of $\mathrm{HCl}$ and then homogenized and left overnight. The next day, the sample was shaken for 2 hours using a shaker and extracted with a pipette of $10 \mathrm{ml}$ into the Erlenmeyer flask. The ion-free water 25 $\mathrm{ml}$ and three drops of Phenolphthalein indicator were added, then titrated with $0.1 \mathrm{~N}$ $\mathrm{NaOH}$ until the color changed into roseate. Titration is also done for the $\mathrm{CaCO}_{3}$ standard and blank sample. The analysis of (\%) carbonates calculated by the formula:

$$
\begin{gathered}
(\%) \text { carbonate equivalent }= \\
\left(m l_{\text {balank }}-m l_{\text {sample }}\right) \times M \times\left(\frac{50}{s} \times f \ldots \ldots\right. \text { (Eq. 5) }
\end{gathered}
$$

Note : $\mathrm{ml}$ blank $=\mathrm{ml}$ of $0.1 \mathrm{~N} \mathrm{NaOH}$ used for blank titration; $\mathrm{ml}$ sample $=\mathrm{ml}$ of $0.1 \mathrm{~N} \mathrm{NaOH}$ used for example titration; $s$ = air-dry sample weight in gram; $\mathrm{M}=$ molarity of $\mathrm{NaOH}$ solution; 50 = equivalent weight of $\mathrm{CaCO}_{3} ;$ Corr. factor $(f)=$ water content correction factor

The relationship between total sediment carbonate content and statistical parameters sediment is measured by simple linear regression analysis (Thomson \& Emery, 2014).

\section{RESULTS AND DISCUSSION}

Carbonate contents determined on treated samples are shown in Figure 3. Carbonate content range from $1.93 \%$ to $6.23 \%$, with an average of $4.21 \%$. The most considerable value located in station 1.2, which a part of cell 1 equal to $6.23 \%$, while the lowest value was in station 7.1 of $1.93 \%$. High carbonate content values were measured in the border cells, both in the west and east 
boundaries. On the eastern edge, high carbonate content at station 1.1 may be related to the input from the karst hill in cell 1. The karst region has a landscape and hydrology with the character formed from carbonate and dolomite rocks due to a combination of soluble rocks, secondary porosity, and some dissolving agents' natural water effect (Ford \& William, 2007). It means the sediment conditions at cell 1 appear to be mixed with white material from the karst.

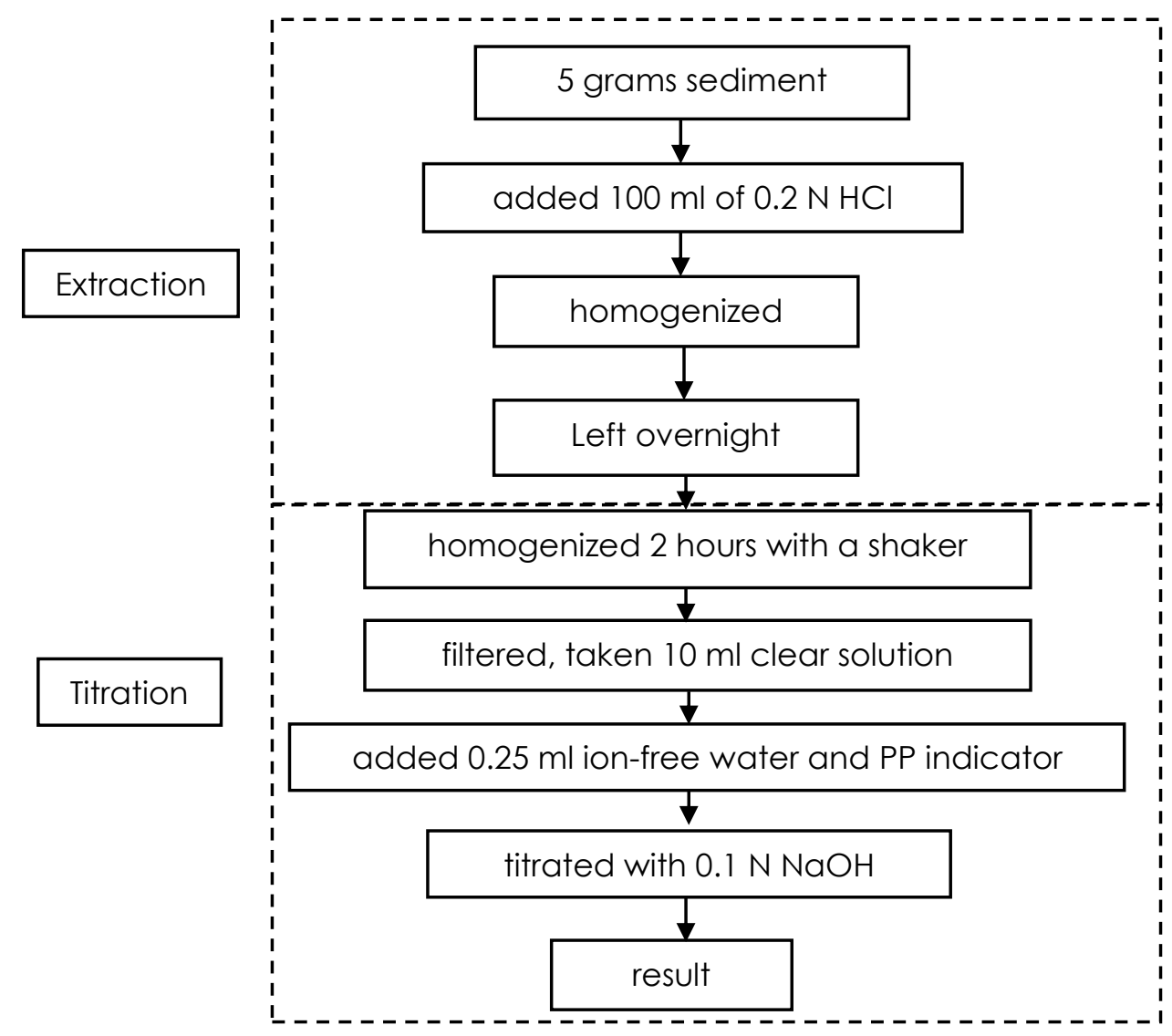

Figure 2. Total carbonate sediment analysis scheme

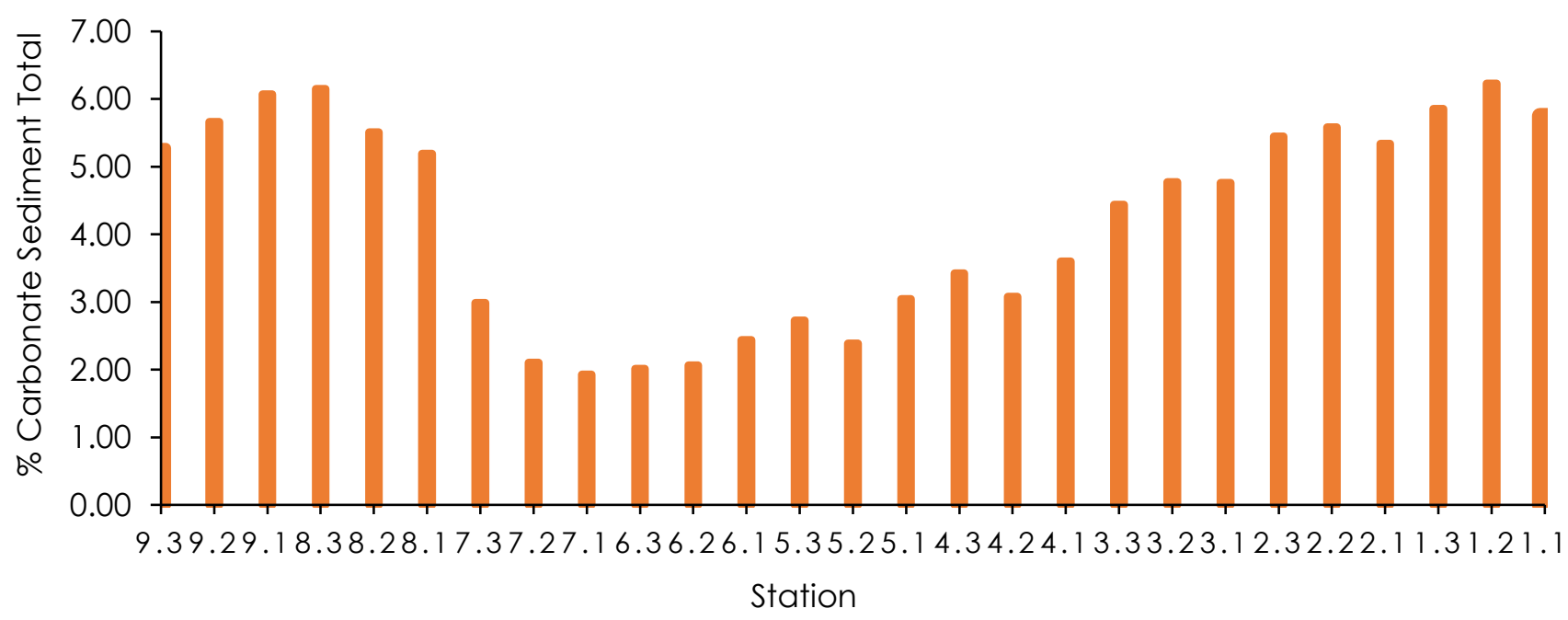

Figure 3. Total sediment carbonate content on the Cilacap coast 
The carbonate content of cell eight and nine increased sequentially with the peak in station 8.3 then decreased to station 9.3. These cells may get input from the sea originating calcium carbonate solution of coral, shells, and mollusks (Woodroffe et al., 2017; Moore \& Wade, 2013). This indication can be seen in the physical properties of sediment mixed with white remains bodies during sampling. The carbonate sediments can vary in density and shape because they come from organic and inorganic sources (Prager et al., 1996). Organic bases, such as corals and crustose coralline algae, may include shells, resulting in complicated skeleton construction and further influencing bulk density (Wang, 2016).

The lowest carbonate content was found in station 6.3 and 7.1, where the Tipar river's mouth and the Serayu River's estuary. Carbonate deposition in river estuaries is categorized as low because of the dynamic processes created by the river's interaction with the sea, such as waves or longshore currents. According to Kutriyani and Trenggono (2018), a robust longshore current has occurred during transitional I, southeast monsoon and is most decisive in transitional II in cells 6.3 and 7.1. Compared to stations in the east and west, both stations are relatively exposed to high energy waves in all monsoons (Kutriyani \& Trenggono, 2018), which resulted in low carbonate deposition in the sediment.

The carbonate content in sediments along the coast of Cilacap was low compared to the research at Rebon beach (Batang Regency), located on the north coast of Java, producing a total carbonate content ranging from 1.51\% - 19.22\% (Sya'rani \& Hariadi, 2006). The shallow waters of the Java sea allow the carbonate rocks to settle well so that the conditions are abundant. In contrast, southern Java's deep waters and extensive wave activities cause carbonates to be distributed far to deeper waters. The low content may be due to differences in the waters' morphology between the northern coast of Java and the coast in Cilacap, south of Java. The shallow waters of the Java sea allow carbonate rocks to be deposited very well so that conditions are abundant.

The distribution of grains size from 27 stations showed in Table 1. The average sediment size is fine sand with a mean size of more than two $\phi$. Meanwhile, for the medium sand category, there are station 1.1, 4.2, 5.3, 6.1, and station 6.3. Overall, the type of sediment that dominates along the coast in Cilacap is fine sand. Currents were due to breaking waves transport the fine fraction in the form of a suspension towards the beach where the samples were taken, while the coarse fraction is deposited faster before reaching the shore. Kutriyani and Trenggono (2018) have assessed the currents due to breaking waves that have been forming along the Cilacap coast during transition monsoon I, although with different strengths. Sediment distribution parameters in this study were obtained through statistical analysis (Hoque et al., 2013). Parameters include sorting, kurtosis, and skewness using the unit of measure phi $(\phi)$ (Table 1). Sorting results from 27 stations showed very well sorted, indicating that the sediment deposits were composed of relatively the same grain size. The evidence can be seen in the mean grain size, which has a small difference in range between fine and medium sand.

The kurtosis includes the very platykurtic category has found in 25 stations (Table 1). Station 7.1 belongs to the extremely leptokurtic category, and station 7.3 the platykurtic type. Bramha et al. (2017) explained that the smaller the kurtosis value, it shows that sediment distribution is getting flattered towards the normal distribution, wherein sediment transport along the coast will move particles with the same properties and are deposited in the same place due to uniformity. Changing leptokurtic to very platykurtic is caused by decreasing inflow direction environmental energy (Bramha et al., 2017). This criterion has shown that the strength of sediment deposition in the study area is lower than the power of its aquatic environment. Kurtosis was found to be predominantly very platykurtic, meaning fine-sized sediments were more ordered in this environment. In general, sediments were dominated by fine-grained are impermeable due to the small size of the pore. If the pores are tiny, the water cannot flow through, although sediment may hold up the water. Consequently, the liquid containing carbonates cannot be trapped in the sediment. 
Table 1. Mean, Sorting, Kurtosis, and Skewness Value

\begin{tabular}{|c|c|c|c|c|c|c|c|c|c|}
\hline \multirow{2}{*}{ St. } & \multirow{2}{*}{$\begin{array}{c}\% \\
\text { Carbonate }\end{array}$} & \multicolumn{2}{|r|}{ Mean } & \multicolumn{2}{|r|}{ Sorting } & \multicolumn{2}{|r|}{ Kurtosis } & \multicolumn{2}{|r|}{ Skewness } \\
\hline & & Size $(\phi)$ & Classification & $\delta_{1}(\phi)$ & Classification & $K_{G}(\phi)$ & Classification & $S K_{1}(\phi)$ & Classification \\
\hline 1.1 & 5.750 & 1.82 & Medium sand & -1.088 & very well sorted & -0.263 & very platykurtic & -0.079 & symmetrical \\
\hline 1.2 & 6.228 & 2.31 & Fine sand & -0.109 & very well sorted & -0.003 & very platykurtic & 18.665 & very fine skewed \\
\hline 1.3 & 5.856 & 2.59 & Fine sand & -0.288 & very well sorted & -0.156 & very platykurtic & -1.842 & very coarse skewed \\
\hline 2.1 & 5.340 & 2.21 & Fine sand & -0.874 & very well sorted & -4.639 & very platykurtic & -0.202 & coarse skewed \\
\hline 2.2 & 5.580 & 2.56 & Fine sand & -0.501 & very well sorted & -0.602 & very platykurtic & -2.158 & very coarse skewed \\
\hline 2.3 & 5.448 & 2.91 & Fine sand & -0.155 & very well sorted & 0.070 & very platykurtic & 13.036 & very fine skewed \\
\hline 3.1 & 4.763 & 2.37 & Fine sand & -0.070 & very well sorted & 0.224 & very platykurtic & -0.187 & coarse skewed \\
\hline 3.2 & 4.774 & 2.62 & Fine sand & -0.258 & very well sorted & -0.132 & very platykurtic & -1.905 & very coarse skewed \\
\hline 3.3 & 4.438 & 2.41 & Fine sand & -0.468 & very well sorted & -0.088 & very platykurtic & -0.014 & symmetrical \\
\hline 4.1 & 3.596 & 2.09 & Fine sand & -0.628 & very well sorted & 0.203 & very platykurtic & -0.743 & very coarse skewed \\
\hline 4.2 & 3.077 & 1.95 & Medium sand & -0.661 & very well sorted & -0.479 & very platykurtic & -0.819 & very coarse skewed \\
\hline 4.3 & 3.424 & 2.43 & Fine sand & -0.610 & very well sorted & -0.133 & very platykurtic & -0.280 & coarse skewed \\
\hline 5.1 & 3.043 & 2.18 & Fine sand & -0.457 & very well sorted & -0.434 & very platykurtic & 2.259 & very fine skewed \\
\hline 5.2 & 2.385 & 2.55 & Fine sand & -0.711 & very well sorted & -0.626 & very platykurtic & -0.253 & coarse skewed \\
\hline 5.3 & 2.727 & 1.69 & Medium sand & -0.983 & very well sorted & -0.373 & very platykurtic & 0.146 & fine skewed \\
\hline 6.1 & 2.438 & 1.75 & Medium sand & -0.371 & very well sorted & -0.342 & very platykurtic & -3.920 & very coarse skewed \\
\hline 6.2 & 2.061 & 2.11 & Fine sand & -0.557 & very well sorted & -0.111 & very platykurtic & -0.825 & very coarse skewed \\
\hline 6.3 & 2.012 & 1.49 & Medium sand & -0.653 & very well sorted & -0.064 & very platykurtic & 0.336 & fine skewed \\
\hline 7.1 & 1.928 & 2.05 & Fine sand & -0.858 & very well sorted & 8.976 & Extremely leptokurtic & -0.061 & symmetrical \\
\hline 7.2 & 2.103 & 2.05 & Fine sand & -1.010 & very well sorted & -0.189 & very platykurtic & -0.099 & symmetrical \\
\hline 7.3 & 2.984 & 2.18 & Fine sand & -0.781 & very well sorted & 0.684 & platykurtic & -0.270 & coarse skewed \\
\hline 8.1 & 5.193 & 2.39 & Fine sand & -0.514 & very well sorted & -0.040 & very platykurtic & -0.045 & symmetrical \\
\hline 8.2 & 5.510 & 2.60 & Fine sand & -0.328 & very well sorted & -0.186 & very platykurtic & -1.712 & very coarse skewed \\
\hline 8.3 & 6.149 & 2.27 & Fine sand & -0.484 & very well sorted & -0.060 & very platykurtic & 0.109 & fine skewed \\
\hline 9.1 & 6.070 & 2.07 & Fine sand & -0.635 & very well sorted & -0.210 & very platykurtic & -0.776 & very coarse skewed \\
\hline 9.2 & 5.663 & 2.01 & Fine sand & -0.640 & very well sorted & 0.078 & very platykurtic & 0.213 & fine skewed \\
\hline 9.3 & 5.275 & 2.20 & Fine sand & -0.865 & very well sorted & 0.332 & very platykurtic & -0.010 & symmetrical \\
\hline
\end{tabular}


Skewness has determined the degree of symmetry or asymmetry of the grain size distribution. Variation in positive and negative value on the results has been observed characterizes the Cilacap coast. The study area's skewness value showed the sediment beach varied between very fine skewed to very coarse skewed (Table 1). Usually, a coast with deposition of sand whereas characterized by positive skewness, while negative skewness is the identity of erosion and non-deposition of the beach (Duane, 1964; Dora et al., 2011; Dora et al., 2014). The very coarse skewed categories were found in nine stations from all stations, indicating uniform grains and sandy sediment types are predominant as wave reworking removes finer sediment and carries it offshore. The coarse type's dominance can increase the permeability of the sediments that can drain fluids containing carbonate. The relationship between the total carbonate content with mean grain size, Sorting, Skewness, and kurtosis in the Cilacap coast showed in Table 2.

Consequently, fine sand can bind carbonate and have the opportunity to contain more than medium sand because carbonate is one of the organic materials. Generally, the carbonate characteristic, which is easily dissolved, allows it to be deposited into the sediment, determined by its porosity and permeability. According to Nurwidyanto et al. (2006), the relationship between porosity and permeability in the medium sand category has a value that is inversely proportional to the sediment's size. The low relationship between carbonate content and grain distribution is presumed because other parameters determine the permeability and porosity factors. A good correlation showed in carbonate content against sorting with a regression coefficient of 0.62 (Table 2). This good correlation indicates the high value of sediment's carbonate content has been affected by sorting conditions dominated by very well sorted states. Well-sorted sediments tend to have higher porosities and permeabilities than poorly-sorted sediments because grains are packed more loosely in these sediments due to coarser sediments filling pore spaces among more refined grains (Boggs Jr., 1995). The high porosity and permeability of sediments have the potential to trap carbonates. The kurtosis value has a very low correlation with carbonate content $\left(R^{2}=0.10\right)$. The dominance of very platykurtic in kurtosis has been revealed the fine-sized presented in the sediments and is thought to be the cause of the pore's small size as a medium for flowing solutions containing carbonates into the sediment.

The low correlation has been shown correlation carbonate content against skewness on symmetrical and fine skewed with a regression coefficient of 0.35 and 0.32 . Simultaneously, an almost low correlation in skewness has been noted in the correlation between carbonate with coarse skewed $\left(R^{2}=0.48\right)$. In general, the coarse skewed type in skewness has the potential to increase permeability. Permeability affects the ability of the sediment to be passed by the carbonate solution. In general, the relationship between carbonate content and sediment statistical parameters is low, even very low, but sorting is the only parameter closely related to carbonate content along the Cilacap coast.

In the middle of two sand types of sediment, a low category correlation was found in medium sand $\left(R^{2}=0.24\right)$. Simultaneously, the relationship of total carbonate content with fine sediment types shows a deficient class $\left(R^{2}=0.11\right)$. The size of sediment is an ecological factor and affected

Table 2. Correlation between Mean, Sorting, Kurtosis, and Skewness.

\begin{tabular}{|c|c|c|c|c|c|c|c|}
\hline \multirow{2}{*}{$\begin{array}{l}\text { Statistical } \\
\text { Parameter }\end{array}$} & \multicolumn{2}{|c|}{ Mean size } & \multirow{2}{*}{$\begin{array}{c}\text { Sorting } \\
\left(\delta_{1}\right)\end{array}$} & \multirow{2}{*}{$\begin{array}{l}\text { Kurtosis } \\
\left(K_{G}\right)\end{array}$} & \multicolumn{3}{|c|}{ Skewness (Sk 1$)$} \\
\hline & $\begin{array}{l}\text { medium } \\
\text { sand }\end{array}$ & $\begin{array}{l}\text { fine } \\
\text { sand }\end{array}$ & & & symmetrical & $\begin{array}{c}\text { coarse } \\
\text { skewed }\end{array}$ & fine skewed \\
\hline R Square & 0.24 & 0.11 & 0.62 & 0.10 & 0.35 & 0.48 & 0.32 \\
\hline $\begin{array}{l}\text { Standard } \\
\text { Error }\end{array}$ & 1.49 & 1.42 & 0.38 & 0.95 & 0.05 & 1.12 & 5.47 \\
\hline
\end{tabular}


the content of organic matter. Theoretically, the finer the substrate texture, the greater its ability to trap organic matter (Nybakken \& Bertness, 2004). In sediment porosity, decreasing grain size means increasing porosity (Gupta \& Ramanathan, 2019).

\section{CONCLUSIONS}

A relatively good correlation between carbonate content with sorting in the Cilacap beach depicted that the beach along Cilacap has well-sorted sediment. Well-sorted sediments have higher porosity and permeability than poorly sorted sediments. This research has shown that carbonate sources are not only the primary determinant of the high carbonate content in coastal sediments. However, the sediment's characteristic in the degree of sorting was a factor that played a role in determining the sediments' porosity and permeability. Further work is needed to evaluate permeability and porosity's direct effect on total carbonate content in the Cilacap coast.

\section{ACKNOWLEDGEMENTS}

The majority of the research was sponsored by Research and Community Service of Jenderal Soedirman University grant for International Research Collaboration with number T/190/UN23.18/PT.01.03/2020, supported by coastal-ocean research teams, are participants in the field survey and laboratory analysis.

\section{REFERENCES}

Ahr, W.M. 2008. Geology of carbonate rocks. Wiley Publication, New York.

Arikunto, S. 2010. Prosedur Penelitian Suatu Pendekatan Praktik. Jakarta: Rineka Cipta.

ASTM (American Society for Testing and Materials) Committee D18. 2000. Standard Test Methods for Amount of Material in Soils Finer Than the No. 200 (75$\mu \mathrm{m})$ Sieve. American Society for testing materials. Annual Book of ASTM Standards, Vol 04.08. West Conshohocken, United States.

Boggs, Jr.M. 1995. Principles of Sedimentology and Stratigraphy Fourth Edition. Pearson Prentice Hall, New Jersey, USA.
Bohnsack, D., Potten, M., Pfrang, D., Wolpert, P., \& Zosseder, K. 2020. Porositypermeability relationship derived from Upper Jurassic carbonate rock cores to assess the regional hydraulic matrix properties of the Malm reservoir in the South German Molasse Basin. Geotherm Energi, 8:12. doi : 10.1186/s405 17-02000166-9.

Bramha, S.N., Mohanty, A. K., Samantara, M. K., Panigrahi, S.N., \& Satpathy, K.K. 2017. Textural characteristics of beach sediments along Kalpakkam, southeast coast of India. Indian Journal of GeoMarine Sciences, 46(8):1562-1574.

Dasgupta, T., \& Mukherjee, S. 2020. Sediment Compaction and Applications in Petroleum Geoscience, Advances in Oil and Gas Exploration \& Production. Springer Nature Switzerland AG. doi : 10.1007/978-3-030-13442-6_2.

Dora, G.U., Kumar, V.S., Philip, C.S., Johnson, G., Vinayaraj, P., \& Gowthaman, R. 2011. Textural characteristics of foreshore sediments along Karnataka shoreline, west coast of India. International Journal of Sediment Research. 269(3):364-377. doi : 10.1016/S1001-6279(11)60100-5.

Dora, G.U., Kumar, V.S., Vinayaraj, P., Philip, C.S., \& Johnson, G. 2014. Quantitative estimation of sediment erosion and accretion processes in a micro-tidal coast. International Journal of Sediment Research. 29(2):218-231. doi : 10.1016/\$10 01-6279(14)60038-X.

Duane, D.B., 1964. West coast of India. Sedimentary Geology, 30(1-2):79-94.

Flóvenz, Ó.G., Hersir, G.P., Saemundsson, K., Ármannsson, H., \& Friðriksson, P. 2012. Comprehensive Renewable Energy. 7:5195. doi : 10.1016/B978-0-08-087872-0.0070 5-8.

Folk, R.L, \& Ward, W.C. 1957. Brazos River Bar, a study in the significance of grain size parameters. Journal of Sedimentary Petrology, 27:3-26.

Ford, M. R., \& Kench, P. S. 2012. The durability of bioclastic sediments and implications for coral reef deposit formation. Sedimentology, 59(3):830842. doi : 10.111 1/j.13653091.2011.01281.x

Ford, D., \& William, P.W. 2007. Karst Hydrogeology and Geomorphology. John Willey and Sons. Chicester. 
Friedman, R. 1978. Kind of Sediment Particle. McGraw-Hill Book Company, New York.

Gupta, A., \& Ramanathan, A.L. 2019. Grain texture as a proxy to understand porosity, permeability, and density in Chandra Basin, India. SN Applied Sciences, 1 (1):1-9. doi : 10.1007/s42452-018-0001-3.

Higgins, J.A., Fischer, W.W. \& Schrag, D.P. 2009. Oxygenation of the ocean and sediments: Consequences for the seafloor carbonate factory. Earth and Planetary Science Letters 284 : 25-33. doi : 10.1016/ j.epsl.2009.03.039.

Hoque, E., Chowdhury, S.R., Uddin, M.M., Alam, M.S., \& Monwar, M.M. 2013. Grain Size Analysis of a Growing Sand Bar at Sonadia Island, Bangladesh. Open Journal of Soil Science. 3(1): 71-80. doi : 10.4236/ojss.2013.32008 P.

Kennedy, D.M., \& Woods, J.L.D. 2013. Determining organic and carbonate content in sediments. In: Shroder, J. (Editor in Chief). Switzer, A.D., Kennedy, D.M. (Eds.), Treatise on Geomorphology. Academic Press, San Diego, CA, vol. 14, Methods in Geomorphology, pp. 262-273. doi : 10.1016/B978-0-12-374739-6.00389-4

Kutriyani \& Trenggono, M. 2018. Studi Angkutan Sedimen Sejajar Pantai (Longshore Transport) di Pantai Kabupaten Cilacap, Jawa tengah. Prosiding Pertemuan Ilmiah Nasional Tahunan XV ISOI 2018. Yogyakarta, November 2018.

Masch, F.D., \& Denny K.J. 1966. Grain size distribution and its effect on the permeability of unconsolidated sands. Water Resource Research, 2:665-677.

Moore C.H., \& Wade W.J. 2013. Carbonate Reservoirs: Porosity and Diagenesis in a Sequence Stratigraphic Framework. Volume $672^{\text {nd }}$ Edition. Elsevier. Poland.

Morrow, N.R., Huppler J.D., \& Simmons, A.B. 1969. Porosity and permeability of unconsolidated, upper Miocene sands from grain size analysis. Journal of Sediment Research, 39:312-321.

Mukherjee, S., \& Kumar, N. 2018. A first-order model for temperature rise for uniform and differential compression of sediments in basins. International Journal of Earth Sciences, 107:2999-3004

National Research Council. 2005. Contaminants in the Subsurface: Source
Zone Assessment and Remediation. Washington, DC: The National Academies Press. 370 pages. doi : 10.17226/11146.

Nichols, G. 2009. Sedimentology and Stratigraphy Second Edition. A John Wiley \& Sons, Ltd., Publication. West Sussex. UK.

Nurwidyanto, M.I., Yustiana, M., \& Widada, S. 2006. Pengaruh Ukuran Butir terhadap Porositas dan Permeabilitas pada Batu Pasir. Jurnal Berkala Fisika, 9(4):191-195.

Nybakken, J., \& Bertness, M. 2004. Marine Biology: An Ecological Approach, Sixth Edition. ISBN-13: 978-0805345827. ISBN10: 0805345825. Benjamin Cummings; 6th Edition (October 18, 2004). 592 pages.

Pilkey, O.H., Morton, R.W., \& Luternaver, J. 2006. The Carbonate Fraction of Beach and Dune Sands. Sedimentology. 8.311327. doi : 10.1111/j.1365-3091.1967.tb013 30.x.

Prager, E.J., \& Southard, J.B., Vivoni-Gallart, E. R. 1996. Experiments on the entrainment threshold of well-sorted and poorly sorted carbonate sands. Sedimentology, 43:3340.

Ridgwell A, \& Zeebe R.E. 2005. The role of the global carbonate cycle in the regulation and evolution of the Earth system. Earth and Planetary Science Letters, 234:299315. doi :10.1016/j.epsl.2005.03.006

Saitoh, M., Ueno, Y., Isozaki, Y., Shibuya, T., Yao, J., \& Ji, Z. 2015. Authigenic carbonate precipitation at the end-Guadalupian (Middle Permian) in China: Implications for the carbon cycle in ancient anoxic oceans. Progress in Earth and Planetary Science, 2(1):1-19. doi : 10.1186/s40645015-0073-2.

Smith, D.A., \& Cheung, K.F. 2002. Empirical Relationships for Grain Size Parameters of Calcareous Sand on Oahu, Hawaii. Journal of coastal research, 1 (1): 82-93.

Sya'rani, L., \& Hariadi. 2006. Penentuan Sumber Sedimen Dasar Perairan Berdasarkan Analisis Minerologi dan Kandungan Karbonat. Jurnal IImu Kelautan, 11(1): $37-43$.

Thomson, R.R., \& Emery, W.J. 2014. Data Analysis Methods in Physical Oceanography Third Edition. Elsevier. Oxford, United Kingdom.

Todd, D.K., \& Mays, L.W. 2012. Groundwater hydrology, 3rd edn. Wiley-India Edition, pp 86-145. 
Trower, E.J., Lamb, M.P., \& Fischer, W.W. 2019. The Origin of Carbonate Mud. Geophysical Research Letters, 46. doi : 10.1029/2018GL081620

van Reeuwijk, L.P. 1993. Technical Paper 9: Procedures for Soil Analysis. International Soil Reference and Information Centre. Wageningen. The Netherlands.

Vousdoukas, M.I., Velegrakis, A.F., \& Plomaritis, T.A., 2007. Beach rock occurrence, characteristics, formation mechanisms, and impacts. Earth Science Reviews 85: 23-46.
Wang. L. 2016. The Ability of Grain Size and Shape to Characterise Siliciclastic, Carbonate, and Mixed Sediments. A VilaConcejo Geocoastal Research Group. The University of Sydney. Sydney. 1 (1):1-21.

Woodroffe, C D., Farrell, J.W., Hall, F.R., \& Harris, P.T. 2017. Calcium Carbonate Production and Contribution to Coastal Sediments. The First Global Integrated Marine Assessment: World Ocean Assessment 1 Cambridge, 1(1): 149-158. 